\title{
CDH17 Gene
}

National Cancer Institute

\section{Source}

National Cancer Institute. CDH17 Gene. NCI Thesaurus. Code C143096.

This gene is involved in cell-cell adhesion and intestinal proton-dependent peptide transport. 